\title{
NEKE AKTUALNE GRAĐANSKOPRAVNE DIMENZIJE KAZNENOG PRAVA I KAZNENOG SUDOVANJA - USTAVNOPRAVNI ASPEKTI
}

Dr. sc. Aldo Radolović, redoviti profesor i sudac,

Pravni fakultet Sveučilišta u Rijeci, Ustavni sud RH

Dr. sc. Duška Šarin, sutkinja

Ustavni sud Republike Hrvatske
UDK: $347: 343$

Ur.: 7. prosinca 2015.

Pr.: 17. ožujka 2016.

Izvorni znanstveni rad

\section{Sažetak}

Ovaj rad tematizira odnos građanskog $i$ kaznenog prava u okvirima kaznenog prava i kaznenog sudovanja.Temeljni je zaključak da je između ovih dijelova prava potrebna veća sinergija jer se bez toga mnoga kaznena djela (napose ona iz zone gospodarskoga kriminala) uopće ne mogu razumjeti, a pogotovo se bez toga ne mogu presuđivati adhezijski civilni zahtjevi koji se postavljaju u okvirima kaznenoga postupka. Isto je tako nužno pravno jače, nomotehnički ispravnije i modernom civilu sukladnije regulirati odgovornost države za štetu uslijed nezakonitih lišavanja slobode. Tu je na ispitu $i$ test države (sudova također) koliko su spremni priznati vlastite pogreške počinjene u suđenju. Rad u svom zaključnom dijelu pledira na stvaranje ,sudskog prava“ kao novog pojma koji bi na prikladan način objedinio nužne točke međusobnog prožimanja građanskog $i$ kaznenog prava. Autori rada povezuju i pitanja međusobne uvjetovanosti građanskog $i$ kaznenog prava s ustavnim pravom i ustavnosudskim postupkom jer bez toga nijedan potpuni zaključak pravno nije moguć.

Ključne riječi: građansko pravo, kazneno pravo, građanski postupak, kazneni postupak, adhezioni građanski postupak u kaznenom postupku, građanski elementi u opisu bića kaznenog djela, nezakonito osuđivanje i neutemeljeno uhićenje, sudsko pravo, ustavno pravo, ustavnosudski postupak, apstraktna kontrola ustavnosti, ustavne tužbe.

\section{UVOD}

Opće je poznata činjenica značaja i utjecaja austrijskog Općeg građanskog zakonika (OGZ) iz 1811. godine na razvoj našeg (hrvatskoga) građanskog prava i prava uopće. 
Poznat je i podatak da je glavni redaktor OGZ-a bio Franz von Zeiller (1751.1828.), profesor prirodnog prava i sudac Vrhovnog suda u Beču.

Manje je, međutim, poznato da je prof. Zeiller bio jedan od redaktora 1. dijela Kaznenog zakona Austrije iz 1803. godine.

$\mathrm{Na}$ domaćem, hrvatskom planu možemo, npr. izdvojiti sličnu situaciju s poznatim odvjetnikom dr. Ivom Politeom (1887.-1956.).

On je prije svega poznat po vrhunskim obranama u mnogim kaznenim procesima, među kojima su poseban odjek imale obrana Josipa Broza 1928. godine u Zagrebu („,bombaški proces“) i zagrebačkog nadbiskupa Alojzija Stepinca 1946., godine, također u Zagrebu.

Dr. Ivo Politeo bio je, međutim, i odličan odvjetnik u građanskim stvarima, a ostavio nam je i više vrijednih znanstvenih radova iz ove oblasti prava. ${ }^{1}$ Njegova zapažanja o kompleksnosti paulijanske tužbe (pobijanje dužnikovih pravnih radnji) i danas su aktualna i predstavljaju ostvarenja neprolazne vrijednosti.

Prethodno ističemo kao "Schlagwort" za temu koju ćemo ovdje razviti: da je danas sve manje prihvatljiva teza o podjeli pravnika, sudaca napose, na „kaznenjake“ i „civiliste“, odnosno da je nužno stvarati jedan sinergijski pojam sudskog pravnika. ${ }^{2}$

Proteklih desetljeća, napose u bivšoj državi i bivšem pravno-političkom sustavu, ovakva je podjela bila potencirana „višim zadacima“ koje su u zaštiti vrijednosti sustava imali kazneni suci. Civilni (građanski) suci i pravnici gurani su na margine prava. U svakom slučaju svaka je od ovih grupa imala svoje posebno i specifično područje djelovanja. ${ }^{3}$

Suvremena društva (hrvatsko također) jesu ili ulaze u fazu više razvojne razine diktirane pojačanim razvojem gospodarskih odnosa koji se odvijaju u jakoj, a ponekad i frenetičnoj konkurenciji (formalno) jednakopravnih subjekata prava.

Uvijek prijeteće pojave kriminala doživljavaju, stoga vrlo jaku pravnu transformaciju: kriminalni interes se s ,krvnog kriminala“ seli na gospodarski teren, s gospodarskim motivima i ciljevima (,kriminal bijelih okovratnika“). Ovaj novi kriminal ne može se pratiti ostane li kazneno pravo u svojim dosadašnjim okvirima. Mutatis mutandis isto vrijedi i u obrnutom smjeru.

1 Navest ćemo ovdje samo neka djela dr. Ive Politea:

- Vanstečajna prinudna nagodba, Hrvatski štamparski zavod, Zagreb, 1923.

- Stečajni zakon za Kraljevinu Jugoslaviju, Zakon o prinudnom poravnanju van stečaja i Zakon o uvođenju u život obiju zakona (sva tri od 22. IX. 1929.), Tipografija, Zagreb, 1929.

- Zakon o suzbijanju nelojalne utakmice (od 4. IV. 1930.), Minerva, Zagreb, 1930.

- Zakon o pobijanju pravnih djela izvan stečaja (od 22. I. 1931.), s predgovorom, Tipografija, Zagreb, 1931.

2 Postoji nekako lažna tradicionalna dilema da li čovjek mora biti „specijalist“ ili „,generalist“. Nakon desetljeća euforije specijalizacije u svemu i svačemu (u medicini na prvom mjestu) čini se da slijedi proces sustavnog (cjelovitog) prilaženja problemima. Modernije rečeno govori se i o "holističkom pristupu“ (na grčkom ,holos"=cio) a taj bi proces i u pravu imao mnogo smisla.

3 Izuzeci su postojali samo kod manjih općinskih sudova (1-2 suca) gdje su se po naravi stvari suci morali baviti i građanskim i kaznenim pravom. No, to svakako nije bila bitna značajka sustava. 
U ovom ćemo radu obraditi samo neke aspekte dodira građanskog i kaznenog prava odn. građanskog i kaznenoga sudskog postupka.

Nećemo, primjerice, obraditi pitanja oduzimanja imovinske koristi, (vrlo važna) prethodna pitanja, problem civilnog vještačenja u kaznenom postupku itd. Ograničavamo se na nekoliko pitanja (koje slijede u nastavku ovoga rada) a koja, po našoj ocjeni, ovog trenutka zaslužuju pažnju i iz teorijskih i iz praktičnih razloga.

Sustavi sudskih postupaka (građanskog i kaznenog) nalaze se konstantno u procijepu između težnje za zakonitošću i težnje za efikasnošću. Pomirenje ovih dvaju načela načelno nije nemoguće, ali je dosta teško i ide uz velike napore, oscilacije i otpore.

Čini nam se da jedino holističko, sinergijsko podizanje profesionalne i stručnoznanstvene kompetencije svih pravosudnih sudionika sudskih postupaka povećava mogućnosti stvaranja uspješnog pravnog i sudskog sustava.

Posebna je zadaća i cilj ovoga rada izdići predmetnu civilno - kaznenu problematiku i na relevantnu ustavnu razinu koja zaokružuje odgovore na postavljena pitanja.

U tom smislu dajemo posebnu glavu ovog rada, mada su i ostali dijelovi teksta pisani tako da traže ustavnopravne odgovore.

\section{TEMELJNE ZASADE MOGUĆNOSTI DA KAZNENI SUD RJEŠAVA GRAĐANSKOPRAVNA PITANJA}

Važeći Zakon o kaznenom postupku Republike Hrvatske (čl. 153.-162. ZKP-a, Glava XI) rabi (i dalje) naziv „Imovinskopravni zahtjev“.

U međuvremenu su se znanost, zakonodavstvo i praksa sudova značajno evoluirali u pravcu da je ,imovinsko pravo“ samo jedan (doduše i sada pretežitiji) dio građanskog prava, odnosno da uz imovinsko pravo postoji i drugi dio neimovinsko građansko pravo, poznat pod nazivom ,ppravo osobnosti““4

Postupovno građansko pravo (Zakon o parničnom postupku - ZPP) uočilo je taj proces pa sada u „udarnom“ čl. 1. toga zakona stoji da građanski sud ne uređuje više samo zaštitu imovinskih odnosa nego je općenadležan za rješavanje ,,... građanskopravnih odnosa“.

Šteta što i ZKP ne slijedi ovakav razvoj ukupnoga građanskog prava. Pravi naziv Glave XI ZKP-a trebao bi zapravo glasiti: „Građanskopravni zahtjevi u kaznenom postupku“. 5

4 Središnja regulacija prava osobnosti u hrvatskom je pravu u Zakonu o obveznim odnosima (NN 35/05 i 41/08). Zakon (ZOO) u relativno malo članaka (st. 2. čl. 19., st. 1. čl. 346., 1048., 1099., 1100., 1105.) sadrži barem temeljnu regulaciju vrlo kompleksnog učenja o pravu osobnosti. Valja tu svakako podvući da ZOO (slijedeći tzv. objektivističku koncepciju prava osobnosti) izjednačava pojmove „,neimovinske štete“ i „povrede prava osobnosti“ (čl. 1046.), a ta je činjenica od veće važnosti i za kazneni postupak. Dijelovi „prava osobnosti“ su i u drugim propisima (o medijima, autorskom pravu, medicinskom pravu itd.).

5 U ovom ćemo radu nastavno reći koji su to zahtjevi, ali na ovom mjestu valja podvući mogućnost pluralizma građanskopravnih zahtjeva, napose stoga da se otkloni moguća zabuna da to može biti samo jedan zahtjev. 
Ovo zaostajanje propisa kaznenog postupka nije samo terminološke prirode; ono može utjecati (i utječe) i na bit gledanja na ovu problematiku. ${ }^{6}$

Adhezioni postupak (Adhaesionsverfahren, adhesional proceding, causa civile nel procedimento penale) obilježava vođenje građanskog (civilnog) postupka unutar (u okvirima) kaznenog prava i kaznenog postupka.

Taj bi postupak (adhezioni, dakle) trebao pridonijeti boljoj i bržoj (efikasnijoj) zaštiti oštećenika, ali i tome da spriječi (zapravo) dvostruko suđenje u povodu istog događaja (najprije kazneno, a onda još i civilno).

$\mathrm{U}$ adhezionom kaznenom postupku oštećenikova se postupovna pozicija olakšava i time 7 što u tom postupku ne mora dokazivati sve činjenične tvrdnje i predlagati dokaze što bi inače (dosta otežano) morao činiti u redovnoj građanskoj parnici. Kazneni sud, naime, izvodeći dokaze u kaznenoj stvari ${ }^{8}$ istovremeno izvodi i dokaze potrebne za odlučivanje o adheziono postavljenom civilnom pitanju. Od nemalog je značaja za oštećenika i to što je adhezioni postupak daleko jeftiniji od redovitoga građanskog postupka (ne plaća, npr. ni pristojbe na tako postavljeni zahtjev).

Riječ ,adhezioni“, kako je poznato, dolazi od latinske riječi adhesio, što znači „pristupam“ (prva osoba jednine glagola adhaere odnosno imenice adhesio). ${ }^{9}$

Ovo pristupanje, pridruživanje i sl. ne smije se, međutim, shvatiti kao pristajanje na nekakvu sporednu ulogu u nečemu čemu se oštećenik ,pridružio“. To nije smisao adhezionog civilnog zahtjeva u kaznenom postupku.

Ovakva adheziona narav civilnog dijela kaznenog postupka je mogućnost, ne i obveza kaznenog suda. Po važećem ZKP-u (arg. iz st. 2. čl. 158.) kazneni sud će oštećenika uputiti na parnicu ,ako podaci iz kaznenog postupka ne daju pouzdanu osnovu ni za potpuno ni za djelomično presuđenje“. Tu je uvijek i dodatna odredba da se o građanskopravnom zahtjevu neće odlučivati „ako bi se time znatno odugovlačio kazneni postupak“" (čl. 153.).

Žalba protiv odluke kaznenog suda da neće rješavati postavljeno građanskopravno pitanje nije dopuštena. ${ }^{10} \mathrm{U}$ prilog takvom rješenju rabi se tradicionalno

6 Postojeća formulacija u ZKP-u napose „Zamračuje“ novo pravo osobnosti gdje u novoj koncepciji ZOO-a svaka neimovinska šteta ipso facto predstavlja i povredu prava osobnosti.

7 To „olakšavanje“ položaja oštećenika ipak nije i bez nekih njegovih obveza; naknada štete koja se uređuje posebnim zakonom (npr. Zakonom o novčanoj naknadi žrtvama kaznenih djela (NN 27/11) ne može se ostvarivati kao adhezioni zahtjev u kaznenom postupku (čl. 4., čl. 43., st. 2. čl. 154. ZKP-a).

8 Tijela kaznenog suđenja dužna su, po postavljenom građanskopravnom zahtjevu, ,ispitati okolnosti koje su važne za utvrđivanje ... zahtjeva" (čl. 157. ZKP-a). To je, čini nam se, dosta preusko i trebalo bi reći da su dužni provesti predložene dokaze, odnosno provjeriti činjenične tvrdnje istaknute u građanskopravnom zahtjevu.

9 Adhezioni karakter civilnih zahtjeva u kaznenom postupku ne treba miješati s problematikom adhezionog zaključivanja ugovora koja u našem obveznom pravu postoji pod pojmom „opći uvjeti ugovora" (čl. 295.-296. ZOO-a).

10 Ovo je, koliko nam je poznato, bio čvrst stav sudske prakse, napose temeljen na tome da se na taj način suštinski materijalnopravni zahtjev oštećenika ne odbija. Čl. 471. st. 3. ZKP-a, međutim, moguće dovodi u pitanje takav stav i ako bi odgovor bio takav da se odluka o 
argument da se takvom odlukom materijalnopravni zahtjev oštećenika suštinski ne odbija.

No, može biti pogrešna prosudba kaznenog suda da nema postupovnih uvjeta iz čl. 153. i 158. ZKP-a. Praksa pokazuje priličnu učestalost takvih pogrešnih prosudbi.

Perzistiranjem stava da se ne može napadati odluka kaznenog suda da neće raspravljati adhezioni civilni zahtjev kazneni se sudovi zapravo potiču na neraspravljanje takvog zahtjeva i to zasigurno nije sukladno zamišljenim ciljevima civilnog postupka unutar kaznenog postupka. Događa se tako da se civilni zahtjev ne raspravlja (i presuđuje) čak ni onda kada on i u osnovi i u visini potpuno korespondira činjenično-pravnom opisu kaznenog djela zbog kojeg se optuženik kazneno optužuje.

Čini se da u postojećoj situaciji valja ozbiljno razmotriti mogućnost revizije postojećih shvaćanja i prakse. ${ }^{11}$

Važeći ZKP (st. 1. čl. 153.) ima još jedan značajan nedostatak koji kaznene suce obeshrabruje od moguće namjere rješavanja adhezionih pitanja.

Propis na odnosnom mjestu, naime, govori da je ,imovinskopravni zahtjev“ onaj zahtjev ,... koji je nastao zbog počinjenja kaznenog djela ...“. To je, zacijelo, dosta neodređeno i već po sebi odvraća kaznenog suca od razmišljanja o građanskopravnim aspektima predmetnog kaznenog postupka.

Raniji je ZKP govorio određenije. Tradicionalno su pravnici učili da se imovinskopravni zahtjev može odnositi na tri zahtjeva: naknadu štete, poništaj pravnog posla i vraćanje stvari. Ni ovi izrazi nisu bili savršeni, ali sadašnja formulacija čini zagonetnim moguće posljedice kaznenog djela s aspekta građanskog prava i stoga kaznene suce od toga odbija.

Po našem mišljenju moguća su samo dva oblika adhezionog civilnog zahtjeva u kaznenom postupku: zahtjev za popravljanje štete i zahtjev za utvrđenje (ili poništenje) pravno relevantne izjave volje ili pravnog posla.

„Popravljanje štete“ zajednički je izraz za sve oblike sanacije počinjene štete te obuhvaća vraćanje stvari (restituciju), naknadu štete u novcu i sve imovinske i neimovinske oblike popravljanja neimovinske štete.

Relevantne izjave volje u građanskom pravu su sve izjave volje koje izazivaju određene građanskopravne posljedice. Pobliži terminus tecnicus za to je ,pravni poslovi“ (to su prije svega ugovori, ali ima i pravnorelevantnih izjava volje, odnosno pravnih poslova koji nisu ugovori, kao npr. izdavanje vrijednosnih papira, javno obećanje nagrada, ponuda i sl.).

neprihvaćanju raspravljanja po postavljenom adhezionom zahtjevu može žalbeno pobijati, mi bismo je pozdravili jer bi bila na liniji raspravljanja tog zahtjeva uvijek kada je to moguće.

11 Njemačka je, npr. 2004. godine značajno izmijenila svoj Zakon o kaznenom postupku upravo poboljšanjem položaja oštećenika kako sudionika u kaznenom postupku tako (istovremeno) i tužitelja u pridruženoj građanskoj parnici (Gesetz zur Verwendung der Rechte von Verletzten im Strafverfahren-t.z. Opferechtsreformgesetz). U objašnjenju prijedloga Zakona posebno je istaknuta nužnost ograničavanja kaznenog suda da otklanja suđenje pridružene civilne stvari. 
U životu je vrlo učestala pojava da kazneni delikt (zbog kojeg se vodi kazneni postupak) predstavlja ujedno i građanski delikt za kojeg je primarno zainteresiran oštećenik. Građanski delikt, odnosno građanska odgovornost je u pravilu pravno šira odgovornost koja postoji čak i kada nema kaznene odgovornosti (npr. objektivna odgovornost za štetu u cestovnom prometu). Zbog toga kada kazneni sud utvrđuje kaznenu odgovornost (a to je prvi uvjet za usvajanje adhezionog civilnog zahtjeva, arg. iz st. 2. čl. 158. ZKP-a) on je time najčešće utvrdio i građansku odgovornost. Utvrditi više (kaznenu odgovornost) uvijek znači obuhvatiti manje (građanska odgovornost).

Kod utvrđivanja nevaljanosti izjava volje, odnosno pravnih poslova situacija je slična. Ako je, naime, kazneno djelo počinjeno povredom oštećenikova prava na slobodno i ozbiljno izražavanje volje (arg. iz st. 3. čl. 249. ZOO-a), logična bi posljedica toga bila i građanskopravna invalidacija takvog ponašanja okrivljenika.

Ni popravljanje štete ni invalidacije nevaljanog pravnog posla ne idu pod pojam „oduzimanje imovinske koristi“. Ta je korist „višak“ koji prelazi štetu i odgovornost za štetu. Ne bi stoga $u$ adhezionom civilnom postupku moglo biti govora i o materiji stjecanja bez osnove (čl. 1111.-1120. ZOO-a) jer stjecanje bez osnove od odgovornosti za štetu dijeli samo to što kod stjecanja bez osnove nema krivnje, odnosno nema štetne radnje. Po obimu odgovornosti tu nema razlike i nema stoga potrebe za formulacijom koja je sada u ZKP-u (,zahtjev ... zbog počinjenja kaznenog djela ... ").

„Oduzimanje imovinske koristi“ odnosi se u kaznenom postupku na oduzimanje ,zarade“ koju je okrivljenik stekao počinjenjem kaznenog djela. To je izvan privatnopravnog zahvata i ne potpada pod materiju adhezionog građanskog postupka u okviru kaznenog postupka.

Postavljanjem adhezionog građanskopravnog zahtjeva u kaznenom postupku nastupa učinak litispendencije (litis pendet). O istom zahtjevu nije stoga više dopuštena redovna građanska tužba. ${ }^{12}$

Kazneni sud mora respektirati neke važne standarde građanskog sudovanja: nema rasprave o civilnom zahtjevu bez tužbe (nemo iudex sine actore), vezan je postavljenom visinom (ne eat iudex ultra et extra petita partium), oštećenik kao tužitelj može svoj zahtjev povući ili promijeniti po odredbama ZPP-a.

No organizacija žalbenog postupka i uopće postupka ulaganja pravnih lijekova je kaznena. To znači da i žalbeni kazneni sud ima pravo i obvezu preispitivanja civilnog dijela osuđujuće kaznene presude. Izvanredni pravni lijek, također je kazneni a ne civilni, ne revizija po ZPP-u nego izvanredno preispitivanje pravomoćne presude (st. 1. čl. 159. ZKP-a).

12 Nejasno bi npr. bilo kad bi oštećenik najprije podnio adhezioni zahtjev na naknadu imovinske štete, a zatim redovnu građansku tužbu radi novčane naknade neimovinske štete („,bolnine“). Čini se da bi to bilo dopušteno i da prigovor litispendencije ne bi bio opravdan. Problem jedino može zakomplicirati činjenica da se iz adheziono postavljenog zahtjeva ne vidi koji se oblik popravljanja štete traži. 


\section{ELEMENTI CIVILA (GRA円ANSKOG PRAVA) U KAZNENOM MATERIJALNOM PRAVU}

Obvezno pravo svakako je najobimnija i najkompleksnija zona civila u kojoj valja napose razlikovati dva njena bitna dijela - ugovorni i izvanugovorni.

Republika Hrvatska ima moderan i vrlo sveobuhvatan propis o obvezama (ZOO, NN 35/05 i 41/08), a brojna druga pravila za obvezne odnose nalaze se u drugim propisima, pravnim običajima, pravilima poslovanja i sl.

Kazneno pravo je uvijek pokazivalo interes za neke ekscesne ispade u obveznom pravu, npr. za lihvarstvo. Lihvarstvo, nazvano „lihvarski ugovor“ je kazneno djelo (čl. 242. KZ-a), ali je i važan razlog civilnopravne nevaljanosti (ništetnosti) pravnog posla (čl. 329. ZOO-a). ${ }^{13}$

U aktualnom hrvatskom kaznenom zakonodavstvu više ne postoji kazneno djelo „zaključivanje štetnog ugovora“. Tržišno gospodarstvo tako nešto ne podnosi, jer slobodni (privatni) subjekt može sklapati bilo kakav ugovor (ovisno o prosudbi svojih interesa), pa ponekad i štetan ako mu to, npr. donosi neki drugi probitak (zadržavanje suradnje s poslovnim partnerom). ${ }^{14} \mathrm{U}$ poslovanju javnopravnih subjekata sankcije za zaključenje štetnog ugovora valja prepustiti njihovim predstavničkim tijelima. ${ }^{15}$

Ugovorno obvezno pravo uvijek značajno određuje ukupne rezultate gospodarskog poslovanja pojedinaca i pravnih osoba koje se time bave.

Kaznena djela protiv gospodarstva (Glava XXIV., čl. 246.-265. KZ-a) predstavljaju odgovornost onih subjekata koji su izazvali poremećaj u poslovanju.

Stečaj nekog subjekta gospodarskog poslovanja uvijek mora biti i kaznenopravno suspektan. Posljedice stečaja negativno se odražavaju na zaposlenike (gube plaću i posao), državu (nema uplate poreza i doprinosa) i vjerovnike (ne naplaćuju potraživanja za isporučenu robu ili izvršenu uslugu). Stečaj, naravno, nije dobar ni za samog subjekta poslovanja, ali to, po naravi stvari, ne može biti objekt ni civilnopravne, a niti kaznenopravne sankcije.

13 Čini se da je, u ovoj usporedbi, regulacija lihvarstva u ZOO-u nešto šira. Čak su i nazivi različiti (ZOO - zelenaški ugovor, KZ - lihvarski ugovor). Mislimo da tu ni u sadržaju ni u formi razlike ne bi smjelo biti.

14 U kaznenom pravu postoji i posebna grana tog prava pod nazivom ,gospodarsko kazneno pravo“. Mada je to pravo zapravo u začecima, praćeno je visokokvalitetnom literaturom (P. Novoselac, Uvod u gospodarsko kazneno pravo, Pravni fakultet u Zagrebu, Zagreb, 2009.).

15 Naše jedinice područne i lokalne samouprave su, između ostalog, i nositelji prava vlasništva na nekretninama, štoviše na posebno atraktivnim nekretninama (građevinsko zemljište). U pravnom prometu tim zemljištima vode se mnogi, dosta razvikani kazneni postupci gdje se napose operira tvrdnjama da je nešto kupljeno ili prodano odnosno zamijenjeno po cijeni koja „nije tržišna“. Potom se, u pravilu, poziva na to da je drukčiju cijenu „utvrdio vještak”. Vještak ništa ne utvrđuje, nego samo daje mišljenje; utvrđuje (odlučuje) samo nadležni sud koji pritom mora imati u vidu da je „tržišna cijena“ isključivo ono što priznaje tržište, a što se (osim uz savjetodavnu pomoć vještaka) napose može utvrđivati usporedbom konkretno sporne cijene s cijenama u sličnim prostornim i vremenskim situacijama. 
Prouzročenje stečaja je kazneno djelo (čl. 249. KZ-a). Kazneno djelo je i pogodovanje vjerovnika (čl. 250. KZ-a) jer pogodovanjem (stavljanje u povoljniji položaj jednog vjerovnika) automatski se u nepovoljniji položaj dovodi drugog vjerovnika, odnosno sve ostale vjerovnike.

U domaćem tržišnom gospodarstvu treba obnoviti značaj pravila iz klasike civila: da je normalno (i jedino normalno!) da vjerovnik naplati svoje potraživanje u iznosu, vremenu i mjestu kako je ugovoreno. Sve izvan toga, napose sve neprihvatljivo ekscesno treba dobiti i zaštitu kaznenog prava.

Razne prisilne kompenzacije, isto takve asignacije, prisilne ili predstečajne nagodbe ${ }^{16}$ ili što slično, kao u osnovi čudnovato preživjeti relikt socijalističke „dogovorne ekonomije“, neprihvatljive su pojave za gospodarstvo koje želi biti tržišno organizirano.

Vjerovnik koji je sukladno ugovoru izvršio svoju obvezu, a nije naplatio tražbinu (ili to ovisi o državnom činovniku u procesu predstečajne nagodbe) dobiva time samo dvije alternative: ili se okrenuti vanjskom tržištu (što uvijek nije lako, napose kad tečaj novca to otežava) ili obustaviti proizvodnju.

Insolvencijsko građansko pravo, vrlo važno i u civilnopravnoj i u kaznenopravnoj zoni, mora stoga kao prvi zaštitni objekt imati u vidu zaštitu ugovornih interesa vjerovnika. ${ }^{17}$

Naknada štete kao drugi bitni dio obveznog prava nalazi se u KZ-u na više mjesta. Najprije kao kazneno djelo oštećenja tuđe stvari (čl. 235. KZ-a) za što oštećeniku uvijek pripada pravo na naknadu štete (ako ju on, naravno, zatraži). Mnogo su, međutim, važnija kaznena djela koja nastaju kao povreda prava osobnosti (čl. 19., čl. 1046. ZOO-a), a zbog čega oštećenici imaju pravo na popravljanje neimovinske štete. Kaznena djela tjelesnih ozljeda (čl. 117.-120. KZ-a), povreda časti i ugleda (čl. 147.-149. KZ-a), povreda spolne slobode (čl. 152.-153. KZ-a), napada na zdravlje ljudi (čl. 180.-182. KZ-a) i dr. ne mogu se razumjeti i pratiti bez poznavanja prava osobnosti. Napose se bez tog znanja ne može uspješno presuđivati adhezioni civilni zahtjev po tim osnovama.

U pitanjima imovinske štete važna je konsideracija da je vraćanje stvari (kad god je moguće) samo po sebi i „naknada“ (tj. popravljanje) štete jer je to prvi i glavni oblik popravljanja štete uopće (čl. 1085. ZOO-a).

16 Poznata je situacija kakva je prošlih godina nastala u vezi s predstečajnim nagodbama u RH. Te su se nagodbe reklamirale kao značajno „dostignuće“ koje „spašava tisuće radnih mjesta kod dužnika“. Zaboravilo se, međutim, pritom reći što je s radnim mjestima kod vjerovnika koji je isporučio robu ili izvršio rad, a to nije naplatio. Propis je imao i druge anomalije, napose npr. da sam dužnik utvrđuje tko je i koliko dužan (!?) kao i da o tome sud praktički ne odlučuje. Novi Stečajni zakon donesen je tijekom 2015. godine (NN 71/05) i stupio je na snagu 1. 9. 2015. Vidljiva su određena poboljšanja u naznačenim pitanjima, ali tek će vrijeme pokazati jesu li pronađena prava rješenja. Međutim, teoretski će ostati pitanje kako u prinudnoj nagodbi (to je njen pravi i tradicionalni naziv) tretirati vjerovnika koji toj nagodbi nije pristupio (pravilo je građanskog prava da pravni posao obvezuje samo onog tko ga je sklopio).

17 U Njemačkoj je 2014. godine značajno reformirano insolvencijsko pravo ("Neues Deutsches Insolvenzrecht"). U raspravi koja je prethodila istaknuta je primarna zadaća Zakona - zaštita interesa vjerovnika. 
Tek ako je tuđu pokretnu stvar nemoguće vratiti ide se na novčanu naknadu. Visina naknade uvijek obuhvaća i vrijednost stvari i izmaklu dobit (čl. 1089. ZOO-a). Visina štete, odnosno visina naknade određuje se prema vrijednosti odnosne stvari na dan presuđenja (st. 2. čl. 1089. ZOO-a) i to je važan valoristički element kojeg mora imati u vidu i građanski i kazneni sudac. ${ }^{18}$ Samo iznimno naknada štete može prelaziti objektivnu vrijednost oštećene stvari i to ako je šteta kaznenim djelom počinjenim namjerno (st. 4. čl. 1089. ZOO-a), u kom slučaju oštećenik može dobiti naknadu ${ }^{19}$ prema vrijednosti koju je stvar imala samo za njega.

Ponešto je kompleksnija dosuda neimovinske štete, ali ne u mjeri koja bi opravdala vladajuće pravilo da se ta šteta u adhezionom postupku ne presuđuje. Postoje određeni standardi (,tabele“, praksa i sl.) koji ne smiju biti nepoznati kaznenom sudu.

Neimovinski oblici popravljanja neimovinske štete (čl. 1099. ZOO-a) isto tako ne bi smjeli biti strani kaznenom sucu; pravilna (istovremena) civilna i kaznena sankcija predstavljaju najbolji odgovor na događaj koji je izazvao intervenciju suda. ${ }^{20}$

Zaštita stvarnih prava (prava vlasništva prije svega) u KZ-u je predviđena $\mathrm{u}$ Glavi XXIII. (čl. 228.-245.). Tuđa pokretna stvar može biti ukradena (čl. 228.-231.), utajena (prisvojena posjedovanjem, čl. 232.), također i pronevjerena ako je bila povjerena na radu (čl. 233.).

KZ ne predviđa slično pravilo za nekretnine. One se, po naravi stvari, ne mogu fizički „ukrasti“, ali nisu nemoguće određene ,akrobacije“" kojima se vlasniku takve stvari protupravno oduzima pravo vlasništva. Zakon o vlasništvu i drugim stvarnim pravima (čl. 125. ZV-a) i Zakon o zemljišnim knjigama (čl. 129.) predviđaju određenu građanskopravnu zaštitu za takve slučajeve, ali ne bi bilo suvišno da se u ovu materiju umiješa i kazneno pravo.

Oduzimanje tuđe pokretne stvari u se civilu sankcionira obvezom vraćanja stvari. Reivindikaciona odnosno publicijanska tužba (čl. 162., čl. 166. ZV-a) jamče vlasniku vraćanje posjeda njegove stvari.

18 Naša pravna znanost i praksa vrlo slabo poznaju i prate monetarno pravo. To je nedostatak kojeg smo naslijedili od Austrije koja nije poznavala inflaciju koja potiče na stvaranje monetarnog prava. Čl. 1089. st. 2. ZOO-a izraz je jednog od pravila suvremenog monetarnog prava da nije oštećena stvar kao takva nego vrijednost koju ona predstavlja i da zato oštećenik (kada dobiva novac za stvar) treba dobiti onoliko koliko ta stvar vrijedi u času kada mu sud dosuđuje naknadu. Protuinflacijske odredbe su uvijek i odredbe o kamatama (minimalno moraju pratiti inflaciju), a dakako i odredbe o valutnim i sličnim klauzulama (čl. 22.-24. ZOO-a).

19 U pitanju je poznata naknada po afekcijskoj (afekcionoj) cijeni. Za kazneni sud se može pojaviti kao značajan aspekt kaznenog djela i kao element odlučivanja o adhezionom zahtjevu. U oba slučaja takva se vrijednost (cijena) ne može odrediti bez sagledavanja osobnosti oštećenika (npr. ubijen mu je pas koji je njemu kao slijepoj osobi bio od bitne pomoći).

20 ZOO (čl. 1099.) kao popravljanje neimovinske štete predviđa i „što drugo“. Prava je šteta da se ova odredba ne koristi kao mogućnost da se štetnika, odnosno osuđenika ne natjera na određeno davanje u dobrotvorne ili humanitarne svrhe. To može pogotovo činiti kazneni sud. 
U adhezionom postupku ova pitanja mogu se vrlo prikladno postaviti, a i odmah riješiti s obzirom na to da se u pravilu kazneni postupak i vodi baš zbog toga da vlasnik opet uspostavi posjedovno stanje koje mu pripada. Oduzimanje predmeta kaznenog postupka (čl. 77.-79. KZ-a) u ovim slučajevima nužno mora ustupiti prednost građanskopravnom zahtjevu (st. 2. čl. 77. KZ-a).

Ostala stvarna prava (pravo služnosti, zaloga, stvarnog tereta i pravo građenja) objektivno su rjeđi predmet kaznene zaštite, ali mogu biti uključena kao kazneno djelo povrede tuđih prava (čl. 241. KZ-a). ${ }^{21}$

Nasljedno pravo, zakonsko i oporučno, također (mada u nešto manjoj mjeri) pobuđuje interes kaznenog prava. Zakonsko nasljeđivanje je dosta standardizirano, dosta jasno u smislu tko ima pravo naslijediti. „Poremećaji“ nasljednih redova prije svega su mogući dostavom lažnih osobnih podataka od strane matičara ili bilježnika i to su onda kaznena djela protiv službene dužnosti (Glava XXIII., čl. 291.-300. KZa) ili kazneno djelo krivotvorenja (Glava XXIII., čl. 274.-283. KZ-a).

Oporučno nasljeđivanje može biti „napadnuto“ pritiscima na slobodno izražavanje volje oporučitelja što potpada pod opću kaznenopravnu zaštitu relevantnih građanskopravnih izjava volje (čl. 236., čl. 243. KZ-a).

Zaštita braka i obitelji je izvan tradicionalnog građanskog prava, ali u širem smislu nedvojbeno spada u privatno pravo. Te su vrijednosti, dakako, uvijek zanimljiv objekt kaznenopravne zaštite (Glava XIII. „Kazneno djelo protiv braka, obitelji i djece“, čl. 167.-179. KZ-a). Živimo u vremenu značajnih promjena u sociologiji braka i obitelji, što je pravo dužno slijediti. U tom smislu nadolaze i neka nova kaznena djela (npr. kazneno djelo povrede privatnosti djeteta, čl. 178. KZ-a) i na te pojave ni građanski ni kazneni sudac ne može ostajati indiferentan.

Naprijed izloženo nije potpuni prikaz elemenata civila u materijalnom kaznenom pravu nego naznaka značajnog obima moguće prisutnosti građanskog prava u kaznenom sudovanju, ali i argument za povećanu sinergiju ovih dijelova prava. Dakako ni građansko ni kazneno pravo nisu samo u jednom zakonu (ZOO, KZ) pa je zadaća koja se nameće mnogo šira.

21 Po našoj ocjeni takvog je kaznenoga gonjenja vrlo malo. Stanje je zapravo razumljivo jer su ova prava po svojoj naravi čisti građanskopravni rezervat. U težim slučajevima ipak valja pribjeći i kaznenopravnoj intervenciji. Među „tuđa prava“ valja navesti i zaštitu prava intelektualnog vlasništva (čl. 282.-290. KZ-a) i posebnu zaštitu nekih drugih prava, prava na slobodu (čl. 135.-140. KZ-a), prava na privatnost (čl. 141.-146. KZ-a) itd. Neka sporna prava iz prava osobnosti u izvjesnoj su koliziji s nekim odredbama civila (npr. st. 3. čl. 112. KZ-a kolidira u izvjesnom smislu s pravom na eutanaziju tamo gdje postoji, a kod nas je nejasno postoji li ili ne, a isto je s čl. 115. KZ-a gdje je predviđeno kazneno djelo protupravnog prekida trudnoće, a dopustivost, odnosno nedopustivost prekida trudnoće moramo cijeniti po Zakonu iz čak 1978. godine - Zakon o zdravstvenim mjerama za ostvarivanje prava na slobodno odlučivanje o rađanju djece, NN 18/78). 


\section{PRAVO NA NAKNADU ŠTETE ZBOG NEOPRAVDANE OSUDE I NEUTEMELJENOG UHIĆENJA}

Naknada štete zbog neopravdane osude i neutemeljenog uhićenja ,skrivena“ je u čl. 573. ZKP-a. Tu su, naime, prijelazne i završne odredbe Zakona (Glava XXIII.), a u alineji 3. se navodi da će se ,do donošenja posebnog zakona i dalje primjenjivati glava XXX. ranijeg ZKP-a” koji je na tom mjestu uredio pravo na naknadu štete za slučajeve nezakonitih kažnjavanja i lišenja slobode.

Predmetni aspekt odgovornosti za štetu vrlo je važan u ukupnoj dijalektici kaznenog postupaka i nije baš primjereno upućivanje važećeg ZKP-a na prije važeći ZKP. Na opisani način regulacije (čl. 573.) ostavlja se gotovo dojam da važeći ZKP ova pitanja čak ni ne uređuje.

Raniji, dakle u ovom dijelu još uvijek važeći ZKP (čl. 476.-484.) sadrži u pitanju naknade štete više posebnih i pravno specifičnih odredbi:

- razlikuje pravo na naknadu u slučaju „neopravdane osude“ (st. 1. čl. 476.) i pravo na naknadu štete zbog neutemeljenog uhićenja (čl. 480.): u oba slučaja je oduzimanje slobode conditio sine qua non cijelog postupanja

- zastara prava na naknadu štete zastarijeva u roku od 3 godine od pravomoćnosti oslobađajuće presude (st. 1. čl. 477.)

- pasivna strana u postupku za naknadu štete je Republika Hrvatska (st. 3. čl. 478.), ali se prije podnošenja tužbe oštećenik mora obratiti Ministarstvu pravosuđa „radi postizanja nagodbe“ (st. 2. čl. 477.) $)^{22}$

- predviđeno je pravo na nasljeđivanje imovinske štete, no samo u okvirima „,već postavljenog zahtjeva“" (st. 1. čl. 479.). ${ }^{23}$

Ako važeći čl. 573. ZKP-a na neki način „,Zamračuje“ značaj i veličinu problema odštetne odgovornosti zbog nezakonita kažnjavanja i lišavanja slobode, znanost prava je - sa svoje strane - dala značajan doprinos problemu i osvijetlila njegove relevantne aspekte. ${ }^{24}$

22 Izraz „radi postizanja nagodbe“ može upućivati na zaključak da se nagodba mora postići. Naravno, da ni sam zakonodavac tako ne misli jer dopušta tužbu. Ipak, pravilno bi bilo reći „radi mogućeg postizanja nagodbe“. Ako dođe do tužbe zahtjev ostaje isti.

23 Bilo bi jako pogrešno da se odredba iz prve rečenice st. 1. čl. 479. ZKP-a tumači restriktivno, tj. da se riječ „naknada imovinske štete“ shvati samo kao imovinska šteta u užem smislu te riječi (obična šteta i izmakla dobit kao oblici štete na stvarima i imovinskim pravima); „imovinska šteta“ treba, naprotiv, obuhvatiti i novčano (imovinsko, materijalno) popravljanje neimovinske štete (čl. 1100. ZOO-a). Ostaje otvoreno pitanje neimovinskih oblika popravljanja neimovinske štete (čl. 1099. ZOO-a). Odredba iz st. čl. 25. Ustava RH govori o „pravu na odštetu“, što može biti samo popravljanje štete u svim njegovim oblicima, imovinskim i neimovinskim.

24 Ukazat ćemo ovdje samo na neke najznačajnije radove: D. Krapac - S. Bagić: Pravo na naknadu štete zbog neopravdane osude ili zbog neutemeljenog uhićenja ili pritvaranja te njegova suvremena ustavnopravna i kaznenopravna regulacija, Zbornik Pravnog fakulteta u Zagrebu, 5-6/2012., str. 1237.-1281.; J. Brežanski, Odgovornost države za štetu u slučaju neopravdane osude ili neosnovanog uhićenja, Zbornik Pravnog fakulteta Sveučilišta u Rijeci, 1/2003, str. 677.-714.; J. Čuveljak, Naknada štete zbog neopravdane osude i neutemeljenog lišenja slobode (www.pravnadatoteka.hr, nepoznato je li objavljeno i u tiskanom izdanju). 
Odgovornost za štetu je sedes materia građanskog prava, pobliže - odštetnog (izvanugovornog) prava u okviru obveznog prava.

Središnji zakon je u tom smislu svakako ZOO. To nije „zakonik“ u smislu hijerarhijske nadređenosti drugim propisima iz odštetne oblasti, tako ni ZKP-u. ZOO je u tom slučaju svakako „opći propis“, a ZKP „posebni propis“.

Moguća prednost ZKP-a u tom smislu ipak ne može ne voditi računa o ukupnoj determiniranosti koja postoji u zoni odštetne odgovornosti:

- valja prvo imati na umu ustavno jamstvo da svatko tko je bio nezakonito lišen slobode ili osuđen ima, u skladu sa zakonom, pravo na odštetu i javnu ispriku (st. 4. čl. 25. Ustava RH); ${ }^{25}$

- drugo, valja imati na umu da obvezno pravo (ZOO) baštini bogato nasljeđe u pravu odgovornosti za štetu i temeljne zasade odštetne odgovornosti ne može mimoići bilo koji posebni propis iz ove zone, napose ne ove:

- da je ,šteta“ zbirni pojam za imovinsku i neimovinsku štetu, odnosno da se imovinska šteta sastoji od umanjenja nečije imovine ili sprječavanja njezina povećanja, a neimovinska od povrede prava osobnosti (arg. iz čl. 1046. $\mathrm{ZOO}-\mathrm{a}) ;{ }^{26}$

- da ZOO (što je izraz općeg stava znanosti odštetnog prava) priznaje pravo na naknadu cjelokupne štete, bez postavljanja limita; $; 7$

- da je pravo na naknadu štete imovinsko pravo koje se nasljeđuje po pravilima nasljednog prava $^{28}$ te

- da obvezno odštetno pravo, napose u njegovim novijim kretanjima, postavlja poseban cilj odštetnog prava da svaki oštećenik dobije naknadu za štetu koju je pretrpio odnosno da mu ta šteta bude popravljena (arg. iz čl. 8 . ZOO-a $)^{29}$.

25 Ustavna odredba o „pravu na odštetu“ svakako je provedena u ZKP-u. Ovaj drugi dio o pravu na ,javnu ispriku“" samo je donekle provedeno u čl. 481. ZKP-a. Mi inzistiramo na stavu da je tu neophodna primjena ZOO-a o zaštiti prava osobnosti i da se o tome vodi opći postupak popravljanja štete, a ne ovaj po ZKP-u.

26 Smatramo doista nužnim povezivanje st. 4. čl. 25. Ustava RH sa st. 1. čl. 1046. ZOO-a. Bez toga postoji rizik davanja parcijalnih i pravno vrlo pogrešnih rješenja.

27 Naš ZOO poznaje, tzv. paušaliziranje naknade štete (st. 3. čl. 345.), ali to se odnosi samo na ugovornu štetu. Mnoge zemlje poznaju taj sustav i za neopravdano lišenja slobode. Njemačka, npr. predviđa 25 eura na dan (Gesetz ueber die Entschaedigung fuer Strafverfolgungsmassnahmen), što se u općoj javnosti karakterizira kao vrlo nedostatno. Isto je tako opća javnost zabilježila najveću datu naknadu od 1,25 milijuna dollara (USA).

28 Čini nam se da ZKP tu ne slijedi do kraja ZOO. Nije jasno zašto bi nasljednik ostvario pravo samo u okviru zahtjeva kojeg je postavio njegov srodnik (arg. iz st. 1. čl. 478. ZKP-a), što bi, npr. bilo s uvijek mogućim računskim greškama? Isto tako - što je s pravom na novčano nasljeđivanje neimovinske štete koje ZOO (čl. 1105.) postavlja dosta liberalno?!

29 Načelo neminem laedere (nikome ne škoditi) ima u modernom obveznom (odštetnom) pravu služiti i kao interpretativno sredstvo u cilju da svi oštećenici ostvare svu naknadu štete. To je važno načelo našeg ZOO-a. 
Suvremeno odštetno pravo napose nastoji poboljšati, podići materijalnopravnu i postupovnopravnu poziciju oštećenika tako da sve šire propisuje objektivnu odštetnu odgovornost štetnika.

Mada je izvorno ovakva (objektivna) odgovornost vezana uz tehniku i tehnologiju, ona danas ide i izvan toga kao neki „sustav bez sustava“. 30

Prvo pravilo odštetnog prava je ipak odgovornost po krivnji; po causa-i se odgovara samo ako je to izrijekom predviđeno. Naš ZOO krivnju presumira (arg. iz st. 1. čl. 1045.) i to svakako ide u prilog oštećeniku. No, ta se njegova prednost može ,istopiti“ ako protivna strana dokaže svoju nekrivnju.

Kod objektivne odgovornosti dokaz nekrivnje štetniku ne pomaže; on će odgovarati i kada nije kriv ${ }^{31}$, a mogućnost eskulpacije (oslobađanje od odgovornosti) priznaje mu se samo u tri slučaja: da je šteta nastala zbog više sile, radnje trećeg i radnje samog oštećenika (arg. iz čl. 1067. ZOO-a). Naravno, teret dokaza ovih razloga je na štetniku.

ZKP u regulaciji prava na naknadu štete slijedi Zakon o sudovima (NN 28/13, 33/15 i 82/15) koji (st. 1. čl. 105.) predviđa odštetnu odgovornost države za štetu koju stranci u postupku nanese sudac svojim nezakonitim ili nepravilnim radom. To je već u zoni objektivne odgovornosti za štetu, ${ }^{32}$ a ZKP ide i na daljnje pojačavanje položaja oštećenika time što štetnu radnju (nezakoniti ili nepravilan rad) i pitanje uzročnosti (kauzalni nexus) uzima kao presumpciju koja se više ne može dovoditi u pitanje.

Nedvojbena objektivna odštetna odgovornost države (RH) pokazuje tu svoju osobinu i time što predviđa mogućnost njene eskulpacije samo ako je osuđenik svojim lažnim priznanjem ili na drugi način namjerno prouzročio svoju osudu, osim ako je na to bio prisiljen (st. 2. čl. 476. ZKP-a).

Ovo nije sporno po građanskom, ali može biti sporno po kaznenom pravu s obzirom na opće pravo okrivljenika da se brani kako želi, da šuti ako želi i da ima pravo na zaštitu od samooptuživanja.

Na razini teorije čini se da bi ovaj eskulpacijski razlog trebalo dosta rijetko i dosta restriktivno primjenjivati.

Država si je u ovom odštetnom području osigurala određeni ,ekskluzivitet“ osuđena se osoba prije tužbe mora njoj obratiti radi (mogućeg) postizanja nagodbe.

30 Suvremena teorija odštetnog prava iz tog širenja (ponekad možda i pretjeranog) objektivne odštetne odgovornosti nalazi podlogu za zaključak da sustav objektivne odštetne odgovornosti nije nikakav sustav i da on ne postoji kao takav (tako npr. V. Vodinelić, Građansko pravo, Beograd, 2012., str. 490.).

31 Odgovornost bez krivnje, koncepcija potpuno suprotna teorijama prirodnog prava o krivnji kao temelju odgovornosti, polazi od bitne činjenice da bez krivnje odgovara onaj tko ima posebnu korist od neke djelatnosti ili ima posebnu odgovornost za tu djelatnost

32 Jasno je pritom da se „nezakonit i nepravilan rad“ tretira kao štetna radnja, a za odgovornost se krivnja smatra irelevantnom. Eskulpacijski razlozi se imaju u vidu (viša sila, radnja trećeg, radnja samog oštećenika), ali relevantan ostaje samo jedan - radnja, ponašanje samog oštećenika (osuđenika). To ide u prilog oštećeniku. Država se, dakle, ne može pozivati na višu silu ili radnju trećeg. 
Povoljno je što za to vrijeme zastara ne teče (st. 2. čl. 478. ZKP-a), što ipak ne otklanja moguće prigovore da za ovaj ekskluzivitet nema razloga.

Postupci naknade štete zbog nezakonitih kaznenih osuda i neutemeljenog uhićenja uvijek pokazuju one slabije strane kaznenog prava i kaznenog postupka. To je na neki način „odjel patologije“ u ukupnom sustavu prava i kaznenog sudstva; tu se ex post pokazuje i vidi gdje je „doktor“" (sudac) pogriješio.

Sociologija kaznenog prava ${ }^{33}$ može tu doći do vrlo dragocjenih zaključaka. I ne s ciljem podizanja histerije oko (ne) odgovornosti sudaca nego radi pobližeg i realnog sagledavanja vrijednosti svih elemenata kaznenog sustava pa i sustava prava u cjelini.

$\mathrm{Na}$ predmetnom planu odštetne odgovornosti svaka društvena zajednica pokazuje svoju spremnost na priznanje i popravljanje počinjenih pogrešaka. To je i na pojedinačnoj i na općoj razini važno etičko pitanje. Upravo bi to, čini nam se, trebao biti veći razlog za punu transparentnost postupaka što bi, primjerice, moglo voditi i tome da postupci ostvarivanja prava ne moraju prethodno ići na relativno nedostupno pregovaranje između države i oštećenika. Po našoj ocjeni neimovinsko popravljanje neimovinske štete ni sada ne podliježe ovoj prethodnoj proceduri.

U uvodu ovog dijela našeg rada (t. 19.) podvukli smo važnu pretpostavku da se mora raditi o oduzimanju slobode.

To proizlazi iz st. 4. čl. 25. Ustava RH koji je temelj ZKP-a u ovome dijelu. Neopravdana osuda bez oduzimanja slobode (npr. uvjetna osuda) ne potpada pod ovu vrstu naknade štete, ni supstancijalno ni postupovno. No, nastala protupravnost (i nastala šteta, napose ona neimovinska) može biti predmet opće pravne zaštite zbog povrede prava osobnosti i odgovornosti za neimovinsku štetu. Članak 481 st. 3. ZKP-a ne udovoljava potrebi ove opće zaštite i ne pokriva razloge zbog kojih je potrebno upućivanje na zaštitu (svih) prava osobnosti.

\section{ODLUKE USTAVNOG SUDA REPUBLIKE HRVATSKE NA GRANICI IZMEĐU GRAĐANSKOG I KAZNENOG PRAVA}

Premda općenito gledano kazneni sudovi nerado prihvaćaju raspravljanje građanskopravnih zahtjeva, u slučajevima kada to ipak čine do Ustavnog suda RH stižu u pravilu samo pritužbe na dosuđenu visinu naknade štete, napose one neimovinske. ${ }^{34}$

33 „Sociologija“ kaznenog, građanskog ili nekog drugog prava kod nas nije posebno razvijena. Na razini studija izučava se opća sociologija što ima izvjesne veze i s pravom, ali ne daje i ne može davati veće odgovore na jače probleme pojedinih pravnih područja. Sociologiju prava zanima samo stvarno, realno stanje stvari što je dragocjena osnovica za veliku analizu načina i stupnja primjene prava. U kaznenom pravu svjedoci smo vrlo pompozno najavljenim i medijski spektakularno praćenim uhićenjima koja potom ne završe ni presudom ni brzim optuženjem, a ponekad izostane i samo optuženje. Sociološki bi doista bilo zanimljivo vidjeti zašto je tome tako, napose jesu li propisi loši ili nešto ne valja u njihovoj primjeni.

34 Predmeti brojeva U-III-2678/2002, U-III-2328/2003, U-III-3776/2003, U-III-2508/2008, U-III-5368/2011, U-III-1248/2012 
Takve se ustavne tužbe gotovo uvijek odbijaju jer Ustavni sud RH ne ispituje građanskopravnu pravilnost dosude nego samo moguće povrede ustavnih prava što pitanja visine naknade štete načelno nisu.

Ustav RH (čl. 35.) jamči građanima štovanje i pravnu zaštitu osobnog i obiteljskog života, dostojanstva, ugleda i časti. Čini nam se da ovakva odredba na području naknade štete, odnosno visine naknade štete dopušta intervenciju Ustavnog suda RH u ustavnopravnom postupanju u povodu ustavnih tužbi samo ako bi po redovnom sudstvu dosuđena naknada štete bila nedostojanstveno niska i takva da se takvom naknadom ne postiže svrha zaštite osobnosti oštećenika (tužitelja u postupku parnice).

$\mathrm{U}$ jednom predmetu ${ }^{35}$ Ustavni sud RH upustio se posredno u ocjenu visine naknade neimovinske štete, smatrajući revizijsku odluku (koja je smanjila naknadu s 80.000,00 kn na 40.000,00 kn), ,samovoljom“.

Na doktrinarnom planu ovakva pravna ocjena može trpjeti značajne kritike. Vrhovni sud RH, naime, ima ustavnu obvezu osiguravanja jedinstvene primjene prava (st. 1. čl. 119. Ustava RH), a, osim toga, pravna narav neimovinske štete je takva da visina te štete nema jednu sigurnu i stabilnu referentnu vrijednost zbog čega je onda teško govoriti da je smanjenje neke konkretne dosude „samovoljno“.

U drugom vrlo zanimljivom slučaju ${ }^{36}$ došlo je do inače, naravno, nedozvoljene litispendencije između adhezionog i općeg parničnog postupka. Oštećenik je, naime, odštetni zahtjev najprije adheziono podnio u kaznenom postupku, a onda (umjesto da traži ovrhu) još jednom u redovnom parničnom postupku. Ustavnu tužbu je podnijela (protiv kasnije presude) tužena koja se našla pred rizikom da zapravo dva puta plati istu dosudu.

Postupovno gledano ova je druga presuda zapravo ništetna ili čak nepostojeća (bez obzira što ove pojmove ZPP ne poznaje), ali je pitanje treba li ju Ustavni sud RH u ime vladavine prava (čl. 3. Ustava RH) ukloniti iz pravnog poretka ili to treba prepustiti redovnim sudovima da oni sami to isto utvrde.

Adhezioni civilni postupci u kaznenom sudovanju, premda građanski po naravi, idu po kaznenoj proceduri i u ustavnosudskom postupku. U općem građanskom postupku ulaganje je redovne revizije uvjet za pristup Ustavnom sudu RH, ali se za adhezionu civilnu stvar ne traži podnošenje zahtjeva za izvanredno preispitivanje kaznene presude koje je pravno sredstvo pandan reviziji u civilu. ${ }^{37}$

U predmetima apstraktne kontrole kaznenog materijalnog zakonodavstva (KZ-a, prije svega) Ustavni sud RH je u više prilika uočio pretjeranu blanketnost odredbi koje određuju biće kaznenog djela u oblasti gospodarskih kaznenih djela.

35 Predmet broj: U-III-576/2000. To je, doduše, bio redovni parnični postupak ali je problem mutatis mutandis isti.

36 Predmet broj: U-III-4433/2011. Do trenutka predaje ovog rada (6.11.2015.) odluka nije donesena.

37 Ovakav je stav Ustavni sud RH ponovio odnosno posebno podvukao na svom 23. Stručnom sastanku od 18. Rujna 2012. 
Ustavni sud RH (ipak) nije prihvatio prijedloge ${ }^{38}$ za ispitivanje ustavnosti čl. 337. i 339. KZ-a, vodeći - osim razloga navedenih u obrazloženju odluke - računa i o tome da je do časa ovog odlučivanja već više tisuća građana bilo osuđeno za ova kaznena djela, odnosno što su već bili na izdržavanju kazne ili su kaznu čak i odslužili.

Kritičari prakse Ustavnog suda RH će možda nedosljednim ocijeniti konkretnu odluku u istoj kaznenoj materiji gdje se ustavna tužba prihvaća i ukidaju donesene redovnosudske odluke. ${ }^{39}$

U oblasti naknade štete zbog neopravdane dosude i neutemeljenog uhićenja na Ustavni sud RH također najviše dolaze ustavne tužbe zbog nezadovoljstva visinom dosuđene naknade.

I tu se ustavne tužbe u pravilu odbijaju jer je intervencija Ustavnog suda RH opravdana samo u slučaju povrede čl. 35. Ustava RH.

Ustavni sud RH inzistira na pravilu da osuđenik (premda oslobođen) nema pravo na naknadu štete kada je svoju štetu sam skrivio. ${ }^{40}$

\section{ZAKLJUČAK}

Vjerujemo da je ova, prmeda kratka, analiza prisustva elemenata građanskog prava u kaznenom pravu, odnosno kaznenom sudovanju potvrdila tezu o neophodnosti sinergije ovih dijelova prava. Takva jedna holistička perspektiva (,holistic approach", ,holistic view“) o neophodnosti spajanja građanskog i kaznenog prava trebala bi dovesti do stvaranja jednoga novog zajedničkog pojma sudskog prava.

Mnoga kaznena djela, napose ona iz sfere gospodarskoga kaznenog prava, ne mogu se razumjeti bez prepoznavanja značajne civilne dimenzije u opisu bića kaznenog djela. Djeluje otužno lutanje naših kaznenih sudaca kada ne razumiju pojam „najpovoljnije ponude“ (pogrešno misleći da se on odnosi isključivo na cijenu), kada im vještak „utvrđuje“ tržišnu cijenu ili kada ne vide razliku između

38 Odluka broj: U-I-1085/2000, U-I-23/2001, U-I-717/2001 i U-I-4025/2005 od 30. travnja 2008. Ova odluka nije donesena jednoglasno jer su suci akademik Davor Krapac i sudac dr. sc. Marko Babić glasali za usvajanje prijedloga i o tome su dali izdvojeno pisano mišljenje.

39 Predmet broj: U-III-5807/2010

40 U predmetu broj: U-III-3244/2006 nije priznato pravo na naknadu štete jer je podnositelj svojim nedopuštenim postupcima prouzročio uhićenje (izbjegavao je primiti poziv za raspravu).

U predmetu broj: U-III-2820/2006 podnositeljici ustavne tužbe nije priznato pravo na naknadu štete jer se šteta odnosila na dobit njenog poduzeća, tj. trgovačkog društva koji je zaseban pravni subjekt. No, na razini teorije civila ovdje valja primijetiti da bi šteta podnositeljice mogla biti u dobiti na koju ona ima pravo (kao vlasnik ili suvlasnik društva) od dobiti društva.

Nije (predmet broj: U-III-839/2003) priznato ni pravo na naknadu štete zbog otkaza radnog odnosa, što pogotovo može biti pravno suspektno kada je prekid, odnosno gubitak radnog odnosa izravno uzročno povezan s neopravdanom osudom ili neutemeljenim uhićenjem. 
ugovora kojim dioničari uređuju način upravljanja dioničarskim poduzećem (suvlasničke stvari) od ugovora o prijenosu dioničarskih (suvlasničkih) prava itd.

Ako se ista civilna dimenzija kaznenog djela ne vidi, nužno se pribjegava i otklonu presuđenja civilnih pitanja u okviru kaznenog postupka. Nužne su tu mjere kojima će se mogućnosti tog otklona bitno smanjiti.

Kazneni sudovi moraju mnogo više imati u vidu da se bitna svrha kaznenopravnog postupka (kažnjavanje počinitelja kaznenog djela) ne može u potpunosti postići ako se za počinjena djela ne izrekne i građanskopravna sankcija uvijek kada je (a to je vrlo često) kazneni delikt ujedno i građanski delikt.

Osobito je značajno koordinirano djelovanje građanskog i kaznenog prava na području odgovornosti za štetu zbog nezakonitog lišavanja slobode.

U tom je smislu odnosne odredbe nužno vratiti u ZKP bez „skrivanja“ u ranije važeći zakon, ali također i obogatiti ih novim tendencijama u bogatoj građanskopravnoj materiji odgovornosti za štetu.

Približavanje građanskog i kaznenog prava zasigurno neće ići tako lako jer su stvorena pravila ponašanja koja će se tome suprotstavljati. Moramo, međutim, znati da takvih podjela u prošlosti (malo daljoj, doduše) nije bilo, a u razvijenijem dijelu svijeta ona ni danas ne postoji. U SAD-u se i kazneni postupak naziva parnicom i tu podjela na kaznene i građanske suce ne postoji. Naš je kazneni postupak, uostalom, postao gotovo potpuno akuzatoran (baš kao civilni) pa je i to dodatni razlog ne samo za nužnost nego i za mogućnost većeg približavanja građanskog i kaznenog prava.

„Sudsko pravo" može predstavljati i vrlo prikladan odgovor na suvremena pitanja razvoja ustavnopravnog sustava Republike Hrvatske u kojem se ovog časa kazneno sudovanje objektivno pokazuje kao jedna od slabijih točaka.

Hrvatsko pravosuđe mora ustrajati na poštovanju temeljnih zasada na kojima se temelji: samostalnosti, neovisnosti i nepristranosti prije svega. Bez toga nema stabilnog pravosuđa, napose ne dobroga sudstva.

No, da bi ta prava opravdalo (i na njima razvijalo vrijednosti koje mu je Ustav namijenio) hrvatsko pravosuđe mora bitno podići razinu svoje efikasnosti. Uz nisku efikasnost, prije ili kasnije, jače ili tiše javljat će se glasovi koji će ugrožavati stabilnu ustavnopravni položaj pravosuđa.

Podizanje pravne kompetencije pravosuđa, u što spada i ovdje elaborirano poticanje sinergije građanskog i kaznenog prava, vjerujemo da u tom pravcu može pomoći.

Uvodno smo rekli da nećemo razmatrati sva zanimljiva pitanja odnosa građanskog i kaznenog prava u kaznenom postupku i kaznenom sudovanju.

Ostavili smo tako izvan domašaja ovoga rada probleme prethodnih pitanja i oduzimanja imovinske koristi.

Provedena analiza ostalih pitanja daje nam, međutim, temelje i za zaključak da se bez jačeg poznavanja građanskog prava ne mogu u kaznenom postupku efikasno rješavati ni prethodna pitanja, ni oduzimati imovinska korist. Kazneni suci će onda „bježati“ od rješavanja prethodnih pitanja (to će onda prepustiti civilnim sucima, ali uz cijenu da to jako produljuje kazneni postupak), odnosno kod oduzimanja 
imovinske koristi sresti će se također s pitanjima koja „ne spadaju u njihovu nadležnost" (pitanja dobre vjere trećih npr.).

Prihvaćanje ovdje predloženog koncepta sinergije građanskog i kaznenog prava moralo bi za posljedicu imati nešto drukčiju organizaciju rada sudova i ostalih dijelova pravosuđa, ali i određenu promjenu u obrazovanju pravnika uopće.

Izvjesno je i da bi naznačena kooperacija građanskog i kaznenog prava u bitnoj mjeri povećala efikasnost i brzinu kaznenog postupka, ali istovremeno i rješavanje pravozaštitnog zahtjeva oštećenih osoba.

Aposteriorna sinteza odgovora također potvrđuje nužnu vezu građanskog i kaznenog prava s ustavnim pravom i ustavnosudskim postupkom. To je na razmatranom planu nova "komplikacija" u čije se rješavanje dobar sudac može i mora upustiti. 


\section{Summary}

\section{SOME TOPICAL CIVIL-LAW DIMENSIONS OF CRIMINAL LAW AND CRIMINAL ADJUDICATION - ASPECTS OF CONSTITUTIONAL LAW}

This paper considers the relationship between civil and criminal law within the framework of criminal law and criminal adjudication.

The basic conclusion is that there should be greater synergy between these two types of law, because, without it, many criminal offences (especially those related to economic crime) cannot be understood, and in particular adhesion civil claims within the framework of criminal proceedings cannot be adjudicated.

It is equally essential to regulate the responsibility of the state for damages incurred due to unlawful deprivations of liberty in a legally sounder, and nomotechnically more precise manner which is better aligned to modern civil law. In this respect, there is a test for the state (and its courts) to assess how prepared they are to admit their own errors in adjudication.

In its concluding part, the paper calls for the creation of "court law" as a new term which would appropriately combine the key points of the mutual intertwining of civil and criminal law.

The authors also link the issues of the inter-conditionality of civil and criminal law to constitutional law and constitutional proceedings, because no full conclusion is legally possible without it.

Keywords: civil law, criminal law, civil proceedings, criminal proceedings, adhesion civil proceedings in criminal proceedings, civil elements in the description of the substance of a criminal offence, unlawful conviction and unfounded arrest, court law, constitutional law, constitutional proceedings, abstract review of constitutionality, constitutional complaints. 


\section{Zusammenfassung}

\section{EINIGE AKTUELLE ZIVILRECHTLICHE DIMENSIONEN DES STRAFRECHTES UND STRAFGERICHTSBARKEIT - VERFASSUNGSRECHTLICHE ASPEKTE}

Diese Arbeit thematisiert das Verhältnis des Zivil- und Strafrechtes in Rahmen des Strafrechtes und Strafgerichtsbarkeit. Die Grundschlussfolgerung ist, dass zwischen diesen Rechtsteilen eine größere Synergie nötig ist, weil man ohne diese Synergie viele Straftaten (vor allem aus dem Bereich der Wirtschaftskriminalität) überhaupt nicht verstehen kann und vor allem können ohne sie die Adhäsionszivilansprüche, die in Rahmen des Strafverfahrens gesetzt werden, nicht verurteilt werden. Außerdem ist es juristisch stärker, nomotechnisch korrekter und dem modernen Zivil übereinstimmender die Staatverantwortung für den Schaden wegen illegaler Freiheitsberaubung zu regulieren. Hier wird auch der Staat (Gerichte auch) getestet, zu welchem Grade man bereit ist, eigene Fehler, die in der Gerichtverhandlung begangen sind, zuzugeben. Die Arbeit plädiert in ihrem Schlussteil auf die Erzeugung des "Gerichtrechtes" als eines neuen Begriffs, der auf angemessene Weise die nötigen Punkte des gegenseitigen Ineinanderflechtens des Zivil- und Strafrechtes zusammenfügt. Die Autoren verbinden außerdem die Fragen der gegenseitigen Bedingtheit des Zivil- und Strafrechtes mit dem Verfassungsrecht und dem verfassungsrechtlichen Verfahren, weil ohne sie keine absolute Schlussfolgerung möglich ist.

Schlusswörter: Zivilrecht, Strafrecht, Zivilverfahren, Strafverfahren, Adhäsionszivilverfahren im Strafverfahren, Zivilelemente in der Beschreibung des Straftatwesens, illegale Aburteilung und unbegründete Verhaftung, Gerichtsrecht, Verfassungsrecht, verfassungsrechtliches Verfahren, abstrakte Verfassungsmäßigkeitskontrolle, Verfassungsmäßigkeitsklagen. 


\section{Riassunto}

\section{ALCUNE ATTUALI DIMENSIONI CIVILISTICHE DEL DIRITTO PENALE E DEL PROCESSO PENALE - PROFILI COSTITUZIONALISTICI}

Il presente lavoro tratta del rapporto tra diritto civile e penale nell'ambito del diritto penale e del processo penale.

La conclusione di fondo è che tra tali ambiti del diritto sia necessaria una maggiore sinergia, poiché altrimenti molti reati (in ispecie quelli nell'ambito della criminalità economica) difficilmente riescono ad essere compresi. Soprattutto, altrimenti non si può decidere delle pretese adesive civili che si innestano nell'ambito del procedimento penale.

Si rende altresì necessario disciplinare giuridicamente in maniera più forte, più corretta sotto l'aspetto della tecnica normativa ed in maniera più consona al diritto civile moderno la responsabilità dello stato in seguito ad un'ingiusta privazione della libertà. Qui è sotto esame anche il test dello stato (e delle corti) su quanto siano pronti a riconoscere i propri errori commessi nel corso del processo.

Nella parte conclusiva del lavoro si caldeggia la creazione di un „diritto giudiziario"; nuova nozione, che unirebbe in maniera adeguata tutti i punti di intersezione del diritto civile e penale.

Gli autori del contributo collegano altresì le questioni del reciproco condizionamento dei diritti civile e penale con il diritto costituzionale e la procedura costituzionale, poiché senza di ciò non è possibile giungere ad alcuna conclusione giuridica compiuta.

Parole chiave: diritto civile, diritto penale, procedimento civile, procedimento penale, procedimento civile adesivo del procedimento penale, elementi civilistici nella descrizione dell'essenza del reato, condanna illegittima ed arresto infondato, diritto giudiziario, diritto costituzionale, procedimento costituzionale, controllo astratto di costituzionalità, ricorso costituzionale. 